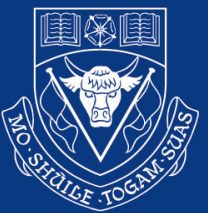

UNIVERSITY OF CALGARY

\title{
IMPLICATIONS OF THE RECOMMENDATIONS OF THE EXPERT PANEL ON FEDERAL SUPPORT TO RESEARCH AND DEVELOPMENT
}

\author{
Preston Manning \\ Manning Foundation for Democratic Education \\ and \\ Jack Mintz \\ The School of Public Policy, University of Calgary
}

\section{SUMMARY}

Canada lags behind many of its First World counterparts when it comes to business innovation, and urgently needs to improve its performance if it is to remain competitive and attractive to investment. The Expert Panel Report on Federal Support to Research and Development has recommended several policy initiatives that governments need to enact to close the gap. This paper reviews all six major recommendations made by the Expert Panel and provides thorough assessments of each, with ample consideration given to their implications for the private sector. The two most promising are: (1) the consolidation of research and development spending programs at the federal level and (2) the adoption of smart procurement as a means of spurring innovation in the non-government sector. While some of the other recommendations need refinement and raise concerns about their impact on the economy, the message for government and business is clear: the former can and should facilitate Canadian business innovation by removing tax and regulatory burdens and facilitating better public-private cooperation, while the latter must make innovation a major part of corporate culture. This paper explains the consequences of the Panel's recommendations for both sectors, identifies the deficiencies, and offers clear-eyed guidance for ameliorating them.

\footnotetext{
* We thank Ken McKenzie, an anonymous referee and participants of the National Policy Dialogue for their comments.
} 


\section{INTRODUCTION}

In its report, Innovation Canada: A Call to Action, the Expert Panel reviews federal support to research and development. ${ }^{l}$ Most of the focus of the report is on business research and its relationship to government and university research. As the report points out, Canada is a particular laggard with respect to business research and development spending, which amounted to $\$ 12$ billion in 2010, only 0.8 percent of Canada's GDP. Yet, Canadian companies are not afraid to invest in risky discovery projects. Exploration and development expenditures by mining and petroleum industries are about twice the total business research and development spending. ${ }^{2}$

Six recommendations are made by the report that will be assessed below. We specifically provide our own view as to the effect that each recommendation will have on business research and the implications for the private sector in terms of its own corporate planning.

\section{PRINCIPLES FOR REFORM}

The Expert Panel lists eight principles to guide program design to promote business innovation, paraphrased as follows: ${ }^{3}$

- Transformative Programs: Programs to support business innovation should focus resources where market forces are unlikely to operate effectively or efficiently;

- Positive Net Benefits: The total benefit of any given program should be greater than its cost;

- National Scope and Broad Application: The core of federal business innovation programs should be national, of substantial scale and broad application;

- Sector Strategies: Beyond broad national programs, complementary programs tailored to the needs of specific sectors should be identified as being of strategic importance;

- Commercial Success: Regionally oriented programs should focus on creating the capacity of firms in the target region to succeed in the arena of global competition;

- Clear Objectives, Appropriate Scale and User-Oriented Approach: A program should be designed to address a specific problem for which a government initiative is needed as part of the solution;

- Flexibility: Federal programs should be innovative and themselves flexible; and,

- Effectiveness: Performance evaluation should be reported regularly with respect to objectives and effectiveness.

1 Expert Panel, Innovation Canada: A Call to Action: Review of Federal Support to Research and Development, Publishing and Depository Services, Public Works and Government Services Canada, Ottawa, 2011.

2 Jack Mintz, “Intangible Taxes," National Post, June 28, 2011.

3 Op cit supra note 1, p. E-5. 
These eight principles are somewhat unmanageable, as some are related to process as opposed to objectives for well-designed innovation programs. So we believe that these principles could be grouped according to three general ones:

(a) Efficiency (transformative programs that are well-designed, broad, and flexible);

(b) Effectiveness (positive net benefits and commercial success); and,

(c) Transparency (regular reporting of performance and published evaluation).

We have concerns with a sectoral approach and the identification of strategic importance as a principle for guiding research and development policy. In principle, the greatest public support should be given to those sectors characterized by large spillovers in research benefiting other parts of the economy. To the extent that it is difficult to measure the size of sectoral spillovers, uniform support for research is provided as exemplified by the current tax support system.

It is well understood that governments have their own priorities for scientific research related to delivery of their own responsibilities (such as defense) and research activity can be contracted out to competitive innovators. However, choosing winning sectors can be a mug's game. As Arnold Harberger pointed out, every decade is influenced by star innovative industries (such as transportation in the 1950s, hi-tech in the 1990s and alternative energy in the current decade) but these are difficult for government to anticipate. ${ }^{4}$ Further, within each industry, one does not know which firms will be "stars" or "dogs" - exceptional or poor performers. As such, the Expert Panel emphasis on broad program support as a core principle is appropriate. We will return to this point later in discussing the fourth recommendation.

The focus on research and development is only part of the overall innovative process. In particular, commercialization is a critical step that brings research and development to productive activities that enhances income gains to the economy. Public policies such as tax credits that reduce the cost of research do not create demand for research. It is also important to have policies that encourage more demand for research such as smart procurement, discussed below.

We do believe, however, that the private sector needs to identify its innovation priorities and that this should be part of its core culture. To assist private sector success, we should identify those barriers to innovation and public policies that undermine innovative activity. One aspect is to provide appropriate regulations (such as patents and copyright laws) to help businesses reap the value of innovation. It could also include direct and tax support for research and development when business innovators bearing the cost cannot fully appropriate returns from innovative activity that benefit others. Further, taxation and regulatory policies should be reformed when they impede innovative activity.

4 Arnold Harberger, “A Vision of the Growth Process," American Economic Review, 88(1), March, 1998, 1-32. 


\section{RECOMMENDATION 1: THE INDUSTRIAL RESEARCH AND INNOVATION COUNCIL}

The first recommendation of the Expert Panel report states:

Create an Industrial Research and Innovation Council (IRIC) with a clear business innovation mandate (including delivery of businessfacing innovation programs, development of a business innovation talent strategy, and other duties over time), and enhance the impact of programs through consolidation and improved whole-of-government evaluation.

This recommendation is consistent with the Expert Panel on Commercialization (2006), the Competition Policy Review Panel (2008) and the Coalition for Action on Innovation (2010).

We support the notion of creating the IRIC with participation by the private sector. However, we question whether the IRIC could be a body that implements policies and programs without being accountable to a single Minister, which will be discussed in more detail with respect of the sixth recommendation. A further concern is that the private sector representatives will not have the time available to perform their duties and potentially be placed in conflict if they are responsible for decisions made by the government with respect to spending programs.

The most important aspect of this recommendation is the consolidation of the over 60 federal research programs that are dispersed among various departments. As the report points out, the only two programs that are well known by the private sector are the federal Scientific Research and Experiential Development (SR\&ED) tax credit program and Industrial Research Assistance Program (IRAP). The rest are hardly known at all.

Consolidation of the myriad of programs into a few well-known programs would increase not only effectiveness but also efficiency and transparency, and would result in better selection and evaluation. As the report documents, it is far from clear that sufficient effort is devoted to assessing the net benefit of the various programs and making these results transparent to Parliament and the Canadian public.

The IRIC could also be made more effective if its mandate were altered to include vigorous promotion among private sector entities with innovation as an explicit goal and integral part of their corporate strategies. 


\section{RECOMMENDATION 2: CHANGES TO THE SR\&ED TAX CREDIT PROGRAM}

The second recommendation of the Panel focuses on improvements to the research and development tax credit that is responsible for 70 percent of spending by the federal government on business innovative activity:

Simplify the Scientific Research and Experimental Development (SR\&ED) program by basing the tax credit for small and medium-sized enterprises (SMEs) on labour-related costs. Redeploy the funds from the tax credit to a more complete set of direct support initiatives to help SMEs grow into larger, competitive firms.

The Panel also recommended that the degree to which the SR\&ED tax credit available to small business is refunded when no income is earned should be reduced. The argument in favour of refundable tax credits is that support is given to risky endeavours since it is not known whether the innovation shall be successful or not. On the other hand, targeting the credit to successful companies encourages those profitable innovations, which are eventually commercialized. Direct spending programs might be a better means to implement risk-sharing since governments are more involved with monitoring the program compared to the SR\&ED tax credit program.

We agree with the general principle of shifting some federal support from indirect to direct support since it would better focus business support, although we are concerned that overly bureaucratic costs could undermine public support for business research compared to the tax credit. We also agree with the principle of awarding success rather than spending on research and development. However, the recommendations made by the Panel seem rather limited in scope.

Next to Spain, Canada has had the most generous system of federal-provincial tax support among the largest industrialized countries (24.4 percent for large firms and 44.3 percent for small firms with over 80 percent of R\&D tax credits claimed by large firms). ${ }^{5}$ Despite this support, Canada has a relatively low rate of business research and development activity. Obviously, something is not working well.

Perhaps one approach to focusing research support is to place more emphasis on direct support programs such as IRAP that benefit small and medium-sized businesses. For large companies, no significant direct program operates as a substitute for tax support. Thus, it is not surprising that the Panel focuses on small and medium-sized businesses as a way to reduce the value of the tax credit.

5 Finance Canada, “An International Comparison of Tax Assistance for Investment in Research and Development," Tax Expenditures, 2009. (http://www.fin.gc.ca/taxexp-depfisc/2009/taxexp0902-eng.asp\#part2). 
We note that the Expert Panel report fails to address several critical issues related to tax support in its recommendations. These include the following:

- The current small business credit rate of 35 percent for research and development at the federal level only applies to very small companies (effectively less than $\$ 15$ million in asset size). If capital costs were to be excluded from costs to determine the credit for both small and medium size businesses, a new size category of corporations would need to be identified as "medium."

- Focusing on only labour costs for the research credit, a practice used in Quebec and some countries, discriminates against capital-intensive research. It is not clear that efficiency improves even if some compliance costs are reduced (compliance costs in determining the eligibility of projects still remains).

- It is not clear that the combined federal-provincial research and development tax credits are provided at an appropriate level of support. The current 20 percent federal credit could be reduced if it is viewed that greater reliance on direct support programs is appropriate.

- The small business research and development tax credit could be viewed as too generous and inefficient. One Finance Canada study indicates that the rate is above the level required to capture the difference between social and private returns. ${ }^{6}$ It is also known that the small business credit encourages the break up of research to small firms that can sell the discovery to larger companies. ${ }^{7}$ Further, the claw-back of the credit as the firm grows in size or spends more on research can discourage research activity. ${ }^{8}$

While the Expert Panel nudges the system away from indirect tax support for small and medium-sized businesses, it fails to provide a braver and more comprehensive approach for reforming the direct and indirect support system for research and development. For example, taking into account reported compliance costs with the tax credit program for small businesses, it does not seem that a credit more than 25 percent is needed to put it on par with larger companies.

The Panel's recommendations will create some incentive for small and medium-sized businesses to use IRAP rather than the tax credit program, especially companies with more capital-intensive projects.

6 Mark Parsons and Nicholas Phillips, "An Evaluation of the Federal Tax Credit for Scientific Research and Experimental Development,” Working Paper 2007-08, Finance Canada, Ottawa 2007.

7 See the Technical Committee on Business Taxation, Report, 1997, chapter 5.

8 See D. Chen and J. Mintz, "Small Business Taxation: Revamping Incentives to Encourage Growth," SPP Research Paper, Vol 4(7), The School of Public Policy, University of Calgary, 4(7), May 2011. 


\section{RECOMMENDATION 3: SMART PROCUREMENT}

The Panel recommends that smart procurement become part of the criteria for government purchases:

Make business innovation one of the core objectives of procurement with the supporting initiatives to achieve this objective.

We strongly support the adoption of smart procurement as an innovation-facilitating policy of the federal government and its application to all federal procurement including services. It is appropriate that criteria should include achieving success in innovation, requiring greater scale in activity. However, less attention should be placed on the size of the firm as opposed to activity.

The merit of this recommendation is that it opens new market opportunities for firms with innovative products and services for sale to the federal government. The opportunities created by the adoption of this policy will very much depend on whether procurement requests for proposals focus on a description of the needs to be met and problems to be solved, rather on technical specifications that leave little room for innovative responses. It will also be important that the government does not use regional criteria to thwart the choice of the most efficient, innovative suppliers.

To demonstrate innovative capacity to government procurement agencies, firms will need to adopt product and service innovation as an explicit corporate goal, integrate R\&D-based innovation into the corporate plan, and use a budget that provides adequate resources to support that activity.

\section{RECOMMENDATION 4: NATIONAL RESEARCH COUNCIL}

The Panel argues for the National Research Council to be changed into a quite different operation:

Transform the institutes of the National Research Council (NRC) into a constellation of large-scale, sectoral collaborative R\&D centres involving business, the university sector and provinces, while transferring NRC public policy-related research activity to the appropriate federal agencies.

The Panel recommends that the NRC evolve over the next several years whereby its units would be transformed as follows:

(a) Industry-oriented non-profit research organizations tasked with collaborative R\&D and commercialization projects and services funded by appropriations and revenues raised from the private sector; 
(b) Basic research entities affiliated with one or more universities and funded by an amount drawn against existing NRC appropriations with contributions from the universities and/or provincial partners;

(c) Parts of non-profit organizations mandated to manage current NRC major science initiatives and potentially other research infrastructure; and,

(d) Institutes or units providing services in support of public policy would be incorporated with the appropriate federal department or agency.

No breakdown of current budgetary expenditures of about $\$ 700$ million is provided in the new format, so the extent to which the various institutes and programs would be funded under sufficient scale without consolidation is unclear. The current NRC has 20 institutes and national programs operating in eight industrial sectors and 18 communities.

We concur that a new approach is needed to encourage more large-scale collaborative centres involving university, business, and government research. One difficulty is whether universities will wish to absorb existing NRC research entities. Another is the inflexibility sometimes arising from a sector-based research focus since some research cuts across different areas. The new IRIC can provide a greater focus if needed.

In our view, various approaches to the type of centre should be considered and not just one form as recommended. Some collaborative research centres require research to be oriented to specific public objectives (e.g., defense-related and medical testing).

The private sector could be engaged with and help fund research with NRC centres. This could be useful for SMEs that do not have the scale needed for research (as mentioned above, most $\mathrm{R} \& \mathrm{D}$ is done by larger firms under the SR\&ED tax credit program). Larger companies may prefer to fund their own research for proprietary reasons.

\section{RECOMMENDATION 5: VENTURE CAPITAL FUNDING}

The Panel recommends specifically one policy to encourage more venture capital funding:

Help high-growth innovative firms access the risk capital they need through the establishment of new funds where gaps exist.

The Panel expressed concern that venture capital funding was insufficient in Canada, particularly with respect to the lack of venture capital financing at the start-up and late stages. The lack of domestic financing, as argued by the Panel, reduces the amount of innovation that is possible in Canada and leads to a potential loss to foreign investors, resulting in less access to technologies originally produced in Canada.

Specifically, the Panel recommends that the BDC should allocate a larger portion of its portfolio to start-up stage financing with sidecar funds formed with angel investors. The BDC should also develop large-scale, later-stage venture capital funds and growth equity funds to support private venture capital, specializing in deal sizes of $\$ 10$ million and above managed by the private sector and subject to appropriate governance practice. 
In our view, the analysis does not provide sufficient grounds to support this recommendation. Outside of remarking that Canadian venture capital financing is less than that found in the United States, no evidence of an existing gap is provided by the report. A gap arises from demand for venture capital projects being more than the amount of financing available even if the lending rates reflect risk and information costs.

If a gap arises, it needs to be explained. One possible explanation arises from informational asymmetries whereby lenders cannot judge between good and bad projects (which is better known by the innovator). Lenders may not be willing to invest in good projects because they cannot judge the quality, thereby leading to a gap.

On the other hand, innovators often think they have good projects even though lenders know well that the project cannot succeed. This is not a funding gap.

While it is true that asymmetric information results in a market failure whereby the low-quality borrowers increase the cost for the better-quality borrowers, the public policy solution to these issues requires careful analysis. ${ }^{9}$ Specifically, public subsidies for equity financing of venture capitalists could increase the number of bad projects entering an industry, making it harder for lenders to determine the quality of projects. Rather than reducing the gap, it is increased.

The success of venture capital funding requires investors to have sufficient scientific and business knowledge to judge the quality of projects. Large-scale venture capital firms have professional staff, including scientists, who are able to assess projects at lower information costs.

The recommendation of the Panel to increase BDC involvement in lending works best if the BDC develops the professional staff needed to ascertain project quality. Our understanding is that it has been developing the professional expertise in this area. The BDC should be able to earn income on its portfolio of investments - otherwise, venture capital funding could be subsidized, leading to too many poor projects entering the industry.

Nonetheless, increased funding from the BDC for venture capital could have poor economic consequences. Funds created with BDC involvement could crowd out private funds that would charge higher financing terms to compensate for risk. This is an issue that has arisen with competition between private and government financial intermediaries in the past. Further, a government-sponsored bank might become the lender of last resort and take on risky projects that have a higher incidence of failure.

It is disappointing that the Panel did not look at other policies to encourage venture capital funding and late-stage selling of assets to other Canadian residents. For example, it would have been good to assess Labour-Sponsored Venture Capital tax credits, which in recent years were dropped by the province of Ontario. These tax credits given to investors have not been a successful means to support venture capital funding. As studies have shown, economic returns to venture capital funds have been low or negative in the past and have crowded out private sector funding. ${ }^{10}$ Investors, receiving public support for the majority cost of investments, pay less attention to economic success of projects. Ultimately, the poor performance of these taxsupported ventures make it more difficult for private venture capitalists to raise funds from other investors, such as pension funds, who perceive that the return on investments is mediocre. The savings could have been used for other incentives that could work more effectively.

9 Mintz, Jack M. 1997. "Policy Perspectives on Capital Market Issues." In Paul J. N. Halpern, ed. Financing Growth in Canada. Calgary: University of Calgary Press.

10 Douglas Cumming and Jeffrey MacIntosh, “Crowding Out Private Equity: Canadian Evidence,” Journal of Business Venturing, 21, 569-609, 2006. 
For example, there is little discussion in the report of capital gains taxes, which can operate as a barrier to venture capital investors. Recently, changes to the withholding tax measures will make it somewhat easier for large venture capital pools from the United States to participate in Canadian capital markets. The federal government has also enabled investors to replace shares of Canadian-controlled private corporations (CCPCs) with shares of other CCPCs without triggering capital gains taxes that could be deferred. However, one could expand the definition of assets eligible for rollovers to encourage more venture capital funding.

Similarly, the United States provides an incentive for companies to go public by reducing capital gains taxes by a half (so long as the public corporate shares are held by investors for certain length of time). A similar incentive in Canada could encourage companies to stay under Canadian ownership.

\section{RECOMMENDATION 6: FEDERAL VOICE OF INNOVATION}

The last recommendation made by the Panel states:

Establish a clear federal voice for innovation and engage in a dialogue with the provinces to improve coordination and impact.

The Panel recommends the designation of a lead minister responsible for innovation policy and national dialogue with the provinces and private sector. It also recommends establishing the Innovation Advisory Council to the Minister, which would be a successor to the Science, Technology and Innovation Council. The mandate of the Council would be to provide advice on goals, program evaluation and effectiveness and new initiatives. The Council would have two subcommittees for business innovation and science and research.

While we recognize that having a voice within government on innovation policy has some merit, we are uncertain of its application. For example, taxation is the responsibility of Finance Canada and it is unlikely that the largest program for R\&D support would be given to a different department. With respect to the numerous direct support programs, consolidation might result in some activities that might be better allocated to a department such as Industry Canada.

It is still possible to have a Minister responsible for coordinating innovation policies in the federal government. However, the minister has little ability to change policies that are under the purview of another minister.

As for the Innovation Advisory Council, it would have some value in advising the government, but would need to be assigned to a minister for reporting purposes. If the IRIC were a government body with its own responsibilities, an advisory council to identified ministers with private sector participation would be useful.

We strongly agree with the Panel that greater transparency is needed with respect to measuring the success of innovation policies in Canada. This would include evaluations of programs especially with respect to their net benefit to society. 


\section{CONCLUSIONS}

The Expert Panel report provides six recommendations to improve innovation policy at the federal level. We believe the Panel has made important contributions in some areas: the need to consolidate programs, partial shifting from tax to direct support for research and development, smart procurement and a more engaged role for NRC programs with universities and business.

As the Panel points out, there is still much more to understand to determine the effectiveness of business innovation policies in Canada. Since business innovative performance has been poor, bolder changes are needed to make a bigger difference in the future.

It is important that the federal government assess the success of its innovation programs and take steps to encourage both research and its commercialization. In the end, the objective is to harness resources so as to create more income for Canadians.

\section{About the Authors}

Preston Manning served as a Member of the Canadian Parliament from 1993 to 2001. He founded two new political parties - the Reform Party of Canada and the Canadian Reform Conservative Alliance - both of which became the official Opposition in the Canadian Parliament. Mr. Manning served as Leader of the Opposition from 1997 to 2000 and was also his party's critic for Science and Technology. In 2007 he was made a Companion of the Order of Canada.

Since retirement from Parliament in 2002, Mr. Manning has released a book entitled Think Big describing his use of the tools and institutions of democracy to change Canada's national agenda. He has also served as a Senior Fellow of the Canada West Foundation and as a Distinguished Visitor at the University of Calgary and University of Toronto. He is a member of the Institute of Corporate Directors and is an Institute Certified Corporate Director.

Mr. Manning is currently a Senior Fellow of the Fraser Institute and President and CEO of the Manning Centre for Building Democracy.

\section{Dr. Jack Mintz}

\section{The James S. \& Barbara A. Palmer Chair in Public Policy}

Jack M. Mintz was appointed the Palmer Chair in Public Policy at the University of Calgary in January 2008.

Widely published in the field of public economics, he was touted in a 2004 UK magazine publication as one of the world's most influential tax experts. He serves as an Associate Editor of International Tax and Public Finance and the Canadian Tax Journal, and is a research fellow of CESifo, Munich, Germany, and the Centre for Business Taxation Institute, Oxford University. $\mathrm{He}$ is a regular contributor to the National Post, and has frequently published articles in other print media.

Dr. Mintz presently serves on several boards including Brookfield Asset Management, Imperial Oil Limited, Morneau Shepell, and the Social Sciences and Humanities Research Council. He was also appointed by the Federal Minister of Finance to the Economic Advisory Council to advise on economic planning and served as research director for the Federal-Provincial Minister's Working Group on Retirement Income Research.

Dr. Mintz held the position of Professor of Business Economics at the Rotman School of Business from 1989-2007 and Department of Economics at Queen's University, Kingston, 1978-1989. He was a Visiting Professor, New York University Law School, 2007; President and CEO of the C.D. Howe Institute from 1999-2006; Clifford Clark Visiting Economist at the Department of Finance, Ottawa; Chair of the federal government's Technical Committee on Business Taxation in 1996 and 1997; and Associate Dean (Academic) of the Faculty of Management, University of Toronto, 1993-1995. He was founding Editor-in-Chief of International Tax and Public Finance, published by Kluwer Academic Publishers from 1994-2001, and recently chaired the Alberta Financial and Investment Policy Advisory Commission reporting to the Alberta Minister of Finance. In 2002, Dr. Mintz's book, Most Favored Nation: A Framework for Smart Economic Policy, was winner of the Purvis Prize for best book in economic policy and runner-up for Donner Prize for best book in public policy.

Dr. Mintz has consulted widely with the World Bank, the International Monetary Fund, the Organization for Economic Co-operation and Development, the governments of Canada, Alberta, New Brunswick, Ontario, and Saskatchewan, and various businesses and nonprofit organizations. 


\section{ABOUT THIS PUBLICATION}

The School of Public Policy Research Papers provide in-depth, evidence-based assessments and recommendations on a range of public policy issues. Research Papers are put through a stringent peer review process prior to being made available to academics, policy makers, the media and the public at large. Views expressed in The School of Public Policy Research Papers are the opinions of the author(s) and do not necessarily represent the view of The School of Public Policy.

\section{OUR MANDATE}

The University of Calgary is home to scholars in 16 faculties (offering more than 80 academic programs) and 36 Research Institutes and Centres including The School of Public Policy. Under the direction of Jack Mintz, Palmer Chair in Public Policy, and supported by more than 100 academics and researchers, the work of The School of Public Policy and its students contributes to a more meaningful and informed public debate on fiscal, social, energy, environmental and international issues to improve Canada's and Alberta's economic and social performance.

The School of Public Policy achieves its objectives through fostering ongoing partnerships with federal, provincial, state and municipal governments, industry associations, NGOs, and leading academic institutions internationally. Foreign Investment Advisory Committee of the World Bank, International Monetary Fund, Finance Canada, Department of Foreign Affairs and International Trade Canada, and Government of Alberta, are just some of the partners already engaged with the School's activities.

For those in government, The School of Public Policy helps to build capacity and assists in the training of public servants through degree and non-degree programs that are critical for an effective public service in Canada. For those outside of the public sector, its programs enhance the effectiveness of public policy, providing a better understanding of the objectives and limitations faced by governments in the application of legislation.

\section{DISTRIBUTION}

Our publications are available online at www.policyschool.ca.

\section{DISCLAIMER}

The opinions expressed in these publications are the authors' alone and therefore do not necessarily reflect the opinions of the supporters, staff, or boards of The School of Public Policy.

\section{COPYRIGHT}

Copyright (C) 2012 by The School of Public Policy.

All rights reserved. No part of this publication may be reproduced in any manner whatsoever without written permission except in the case of brief passages quoted in critical articles and reviews.

\section{ISSN}

1919-112x SPP Research Papers (Print) 1919-1138 SPP Research Papers (Online)

\section{DATE OF ISSUE}

March 2012

\section{MEDIA INQUIRIES AND INFORMATION}

For media inquiries, please contact Morten Paulsen at 403-453-0062.

Our web site, www.policyschool.ca, contains more information about The School's events, publications, and staff.

\section{DEVELOPMENT}

For information about contributing to The School of Public Policy, please contact Candice Naylen by telephone at 403-210-7099 or by e-mail at cnaylen@ucalgary.ca.

\section{EDITOR}

Timothy Giannuzzi 


\section{RECENT PUBLICATIONS BY THE SCHOOL OF PUBLIC POLICY}

DEPARTURES FROM NEUTRALITY IN CANADA'S GOODS AND SERVICES TAX

http:// policyschool.ucalgary.ca/?q=content/ departures-neutrality-canadas-goods-and-services-tax.pdf Michael Smart | February 2012

SOME OBSERVATIONS ON THE CONCEPT AND MEASUREMENT OF INCOME INEQUALITY

http:// policyschool.ucalgary.ca/sites/default/files/research/richardson-comm2.pdf Stephen R. Richardson | February 2012

A REVIEW AND ASSESSMENT OF PRIVATIZATON IN CANADA

http:/ / policyschool.ucalgary.ca/sites/default/files/research/boardman-vining-privatization.pdf Anthony E. Boardman and Aidan R. Vining | January 2012

THE INTERNATIONAL EXPERIENCE WITH PRIVATIZATION: ITS RAPID RISE, PARTIAL FALL AND UNCERTAIN FUTURE

http:/ / policyschool.ucalgary.ca/ sites/default/files/research/nellis-privatization.pdf John Nellis | January 2012

HOUSING SUBSIDIES AND HOMELESSNESS: A SIMPLE IDEA

http:/ / policyschool.ucalgary.ca/sites/default/files/research/oflaherty-housing-subsidy.pdf Brendan O'Flaherty | January 2012

PUBLIC SECTOR WAGE GROWTH IN ALBERTA

http:/ / policyschool.ucalgary.ca/ sites/ default/files/research/boesenkool-public-wage-growth.pdf Ken Boessenkool and Ben Eisen | January 2012

CATCHING THE BRASS RING: OIL MARKET DIVERSIFICATION POTENTIAL FOR CANADA http:/ / policyschool.ucalgary.ca/ sites/ default/ files/research/mmoore-oilmarket.pdf M.C. Moore, S. Flaim, D. Hackett, S. Grissom, D. Crisan and A. Honarvar | December 2011

THE CONSTITUTIONALITY OF FEDERAL CLIMATE CHANGE LEGISLATION

http:/ / policyschool.ucalgary.ca/?q=content/ constitutionality-federal-climate-change-legislation Alastair Lucas and Jenette Yearsley | December 2011

THE MYTHS AND FACTS OF FOSSIL FUEL SUBSIDIES: A CRITIQUE OF EXISTING STUDIES http:/ / policyschool.ucalgary.ca/files/ publicpolicy/MCKENZIE\%20MINTZ\%20online.pdf Kenneth J. McKenzie and Jack M. Mintz | October 2011

HOMELESSNESS IN ALBERTA: THE DEMAND FOR SPACES IN ALBERTA'S HOMELESS SHELTERS http:/ / policyschool.ucalgary.ca/files/publicpolicy/ homelessness\%20in\%20alberta.pdf Ronald Kneebone, J.C. Herbert Emery and Oksana Grynishak | September 2011

THE NEW SECURITY PERIMETER WITH THE UNITED STATES

http:// policyschool.ucalgary.ca/files/ publicpolicy/flemming\%20sept011.pdf

Brian Flemming | September 2011

INCOME SUPPORT FOR PERSONS WITH DISABILITIES

http:// policyschool.ucalgary.ca/files/publicpolicy/Kneebone_Disability_Study.pdf

Ronald Kneebone and Oksana Grynishak I September 2011

INVESTMENT REVIEW IN CANADA - WE CAN DO BETTER

http:/ / policyschool.ucalgary.ca/files/ publicpolicy/Herman\%20Invest\%20Canada\%20online.pdf Lawrence L. Herman | September 2011 